\title{
Synthesis and Evaluation of the Plant Growth Regulatory Activity of 8-oxabicyclo[3.2.1]oct-6-en-3-one Derivatives
}

\author{
Luiz Cláudio A. Barbosa* ${ }^{*}$, Antonio J. Demuner ${ }^{a}$, \\ Eduardo E.L. Borges ${ }^{b}$, and John Mann ${ }^{c}$ \\ ${ }^{a}$ Laboratório de Análise e Síntese de Agroquímicos (LASA), Departamento de \\ Química, Universidade Federal de Viçosa, 36571-000 Viçosa - MG, Brazil \\ ${ }^{b}$ Departamento de Engenharia Florestal, Universidade Federal de Viçosa, \\ 36571-000 Viçosa - MG, Brazil \\ ${ }^{c}$ Chemistry Department, University of Reading, Reading, UK
}

Received: December 7, 1995; September 18, 1996

\begin{abstract}
A síntese de vários análogos do 8-oxabiciclo[3.2.1]oct-6-en-3-ona é relatada. $\mathrm{O}$ efeito desses compostos e do ácido 4-oxoexanóico sobre a germinação e crescimento radicular do Sorghum bicolor foi avaliado. Na concentração de 100 ppm os compostos 3-(metoxicarbonilmetil)-8-oxabiciclo[5.3.0]dec4-eno-2,9-diona (13) e ácido 4-oxoexanóico (17) apresentaram efeito estimulador do crescimento radicular de 33-35\% e a 1000 ppm um efeito inibitório foi observado em ambos os casos (29\% ( 13 ) e $80,2 \%$ (17). Todos os outros compostos inibiram o crescimento radicular a 100 e 1000 ppm. Nenhum efeito significativo foi observado sobre a taxa de germinação.
\end{abstract}

The synthesis of several analogues of 8-oxabicyclo[3.2.1]oct-6-en-3-one is reported. The effect of these compounds and 4-oxohexanoic acid on the germination and radicle growth of Sorghum bicolor was evaluated. At 100 ppm compounds 3-(methoxycarbonylmethyl)-8-oxabicyclo[5.3.0]dec-4-ene-2,9-dione (13) and 4-oxohexanoic acid (17) showed 33-35\% stimulatory radicle growth, and at $1000 \mathrm{ppm}$ a $29 \%$ (13) and $80.2 \%$ (17) inhibition was observed. All the other compounds showed an inhibitory effect on the radicle growth at 100 and $1000 \mathrm{ppm}$. None of the compound had a clear effect on the germination rate.

Keywords: germination, growth inhibition, lactones, [3+4] cycloaddition

\section{Introduction}

A number of sesquiterpene lactones affect plant growth, although the nature and extent of the effects produced depend on a number of factors, including the lactone tested, its concentration, and the species on which it acts ${ }^{1}$. Some sesquiterpene lactones have been reported to be responsible for the allelopathic properties of certain plants by affecting the germination and growth of other species ${ }^{2}$. The potential allelopathic activity of several natural and synthetic sesquiterpene lactones has been investigated and the presence of an $\alpha$-methylene- $\beta$-butyrolactone has been shown be important for the biological activity ${ }^{3}$. The presence of other reactive centres such as $\alpha, \beta$-unsaturated ketone, chlorohydrins, epoxide, hemiacetal, and also the molecules spatial arrangement is normaly important for the biological activity presented by those lactones ${ }^{4-6}$.

As part of our research on the synthesis of new compounds with herbicidal and/or plant growth regulatory activity, derived from the easily available 8-oxabicyclo [3.2.1 ]oct-6-en-3-ones $\mathbf{1}^{7}$, we devised a plan that would allow the preparation of several lactones 3-6 for biological evaluation $^{23}$ (Scheme 1).

\section{Experimental}

\section{Synthesis}

IR spectra were recorded on a Perkin-Elmer 881 double beam grating spectrophotometer. NMR spectra were recorded on a Perkin-Elmer R34 (220 MHz) instrument, a Bruker WH 400 spectrometer (400 MHz) or on a Varian 

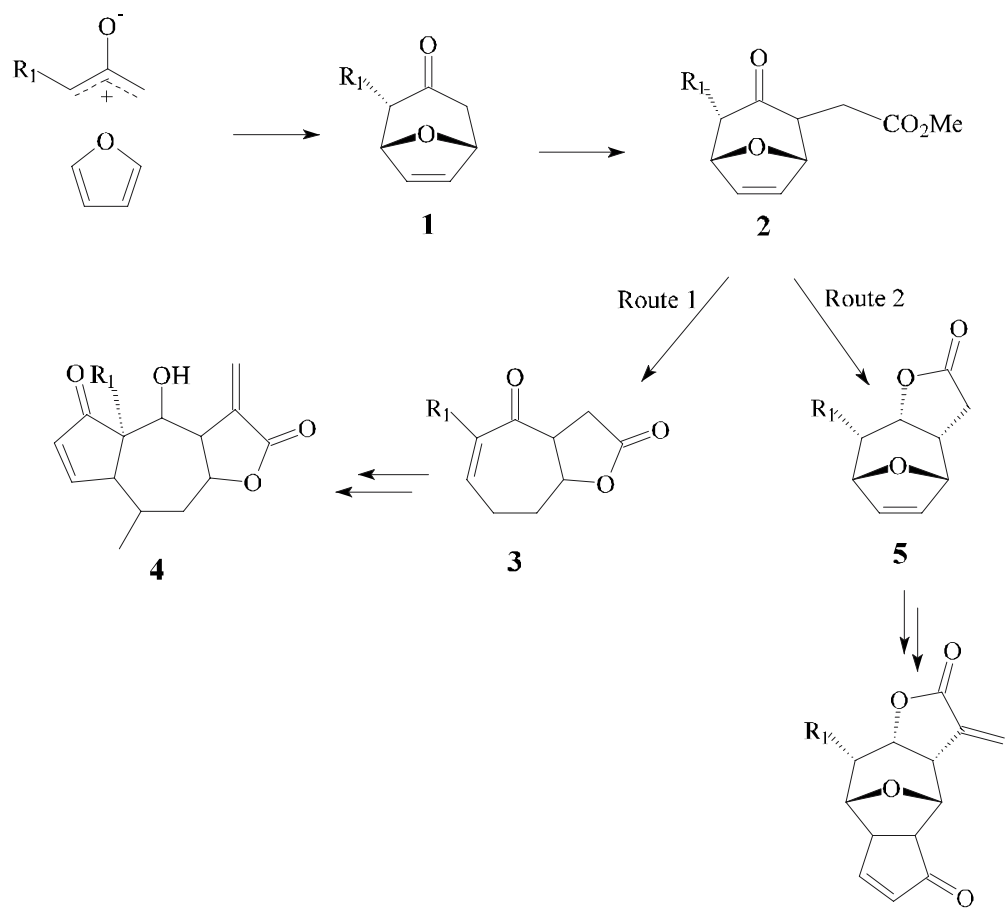

6

Scheme 1.

T-60 (60 MHz) instrument, using tetramethylsilane as internal standard. Mass spectra were obtained on a VG ZAB-E high resolution mass spectrometer. Flash chromatography was performed using Crosfield Sorbsil C60 (40-60 $\mu \mathrm{m})$. Solvents were purified according to Perrin and Armarego $^{26}$, and petroleum refers to the fraction with b.p. 40-60 ${ }^{\circ} \mathrm{C}$, ether refers to diethyl ether.

\section{8-Oxabicyclo[3.2.1]oct-6-en-3-one (7)}

A two litre round bottomed flask was charged with freshly prepared $\mathrm{Zn} / \mathrm{Ag}$ couple (48.83 g, $0.75 \mathrm{~mol}$ ), furan (350 mL, $5 \mathrm{~mol})$, and dry THF (150 mL). The flask was cooled down to $-10{ }^{\circ} \mathrm{C}$ and a solution of 1,1,3,3-tetrabromoacetone (172 g, $460 \mathrm{mmol}$ in $150 \mathrm{~mL}$ of THF) was added dropwise during $2 \mathrm{~h}$ under nitrogen atmosphere. The resulting solution was stirred at room temperature for $17 \mathrm{~h}$. After this period of time the insoluble material was removed by filtration and the solution concentrated to a brown oily residue. This residue $(62.3 \mathrm{~g})$ was dissolved in a saturated methanolic solution of $\mathrm{NH}_{4} \mathrm{Cl}(1000 \mathrm{~mL})$ and freshly prepared $\mathrm{Zn} / \mathrm{Cu}$ couple (200.5 g, $3.1 \mathrm{~mol}$ ) was added. This mixture was stirred at room temperature for 2 $\mathrm{h}$, and then the solid was removed by filtration. The filtrate was divided in three portions and each one was diluted with a saturated solution of $\mathrm{Na}_{2}$ EDTA $(300 \mathrm{~mL})$, followed by extraction with dichloromethane $(4 \mathrm{x} 300 \mathrm{~mL})$. The combined extracts were dried $\left(\mathrm{MgSO}_{4}\right)$ and concentrated to a brown oil, which was purified by flash chromatography (1:2 petrol:ether) to afford $46.5 \%(26.50 \mathrm{~g}, 213.7 \mathrm{mmol})$ of the required oxabicyclo-octane 7 as a pale yellow oil. This oil crystallized on standing, m.p.37-39 ${ }^{\circ} \mathrm{C}$. IR $\left(\mathrm{CHCl}_{3}\right)$ $\bar{v}_{\max }$ : 3080, 2960, 2905, 1710, 1340, 1180, 945 and 710 $\mathrm{cm}^{-1} ;{ }^{1} \mathrm{H}-\mathrm{NMR}\left(60 \mathrm{MHz}, \mathrm{CDCl}_{3}\right) \delta: 2.30(\mathrm{~d}, 2 \mathrm{H}, \mathrm{J}=17 \mathrm{~Hz}$, $\mathrm{H}-2 \alpha$ and $\mathrm{H}-4 \alpha$ ), $2.80(\mathrm{dd}, 2 \mathrm{H}, \mathrm{J}=17$ and $\mathrm{J}=5 \mathrm{~Hz}, \mathrm{H}-2 \beta$ and $\mathrm{H}-4 \beta), 5.10$ (d, 2H, J = 5 Hz, H-1 and H-5) 6.30 (s, 2H, $\mathrm{H}-6$ and $\mathrm{H}-7)$; MS m/z(\%): 124( $\left.\mathrm{M}^{+}, 80\right), 95(10), 82(90)$, 81(100), 68(10), 54(10).

\section{8-Oxabicyclo[3.2.1]octan-3-one (8)}

8-oxabicyclo[3.2.1] oct-6-en-3-one 7 (26 g, 209 mmol) was dissolved in ethyl acetate $(150 \mathrm{~mL})$, in a Parr hydrogenation bottle and $10 \% \mathrm{Pd}-\mathrm{C}(1.5 \mathrm{~g})$ was added as a catalyst. The reaction was carried out under $3.0 \times 10^{5} \mathrm{~Pa}$ of hydrogen pressure, for $5 \mathrm{~h}$. When the hydrogen uptake ceased, the catalyst was filtered off through a Celite pad and the solvent evaporated under reduced pressure. The reduced product $\mathbf{8}$ was obtained as a yellow oil, in quantitative yield (26.33 g, $209 \mathrm{mmol})$. IR (thin film) $\bar{v}_{\text {max }}: 2940,2840,1720$, 1470,1410 and $1205 \mathrm{~cm}^{-1} ;{ }^{1} \mathrm{H}-\mathrm{NMR}\left(220 \mathrm{MHz}, \mathrm{CDCl}_{3}\right) \delta$ : 1.72-1.84 (bd, $2 \mathrm{H}, \mathrm{J}=5 \mathrm{~Hz}, \mathrm{H}-6_{\text {endo }}$ and $\mathrm{H}-7_{\text {endo }}$ ), 2.00-2.18 (m, 2H, H- $6_{\text {exo }}$ and H-7 exo), 2.29 (dm, $2 \mathrm{H}, \mathrm{J}=16 \mathrm{~Hz}, \mathrm{H}-2 \alpha$ and $\mathrm{H}-4 \alpha$ ), 2.72 (dd, $2 \mathrm{H}, \mathrm{J}_{1}=16$ and $\mathrm{J}_{2}=5 \mathrm{~Hz}, \mathrm{H}-2 \beta$ and H-4ß), 4.75 (m, 2H, H-1 and H-5); MS m/z: $126.0672\left(\mathrm{M}^{+}\right.$, $\mathrm{C}_{7} \mathrm{H}_{10} \mathrm{O}_{2}$ requires 126.0678 ). 


\section{3-Trimethylsilyloxy-8-oxabicyclo[3.2.1]oct-2-ene (9)}

Trimethylsilylchloride $(1.02 \mathrm{~mL}, 0.87 \mathrm{~g}, 8.06 \mathrm{mmol})$ was added via syringe to a stirred solution of ketone $\mathbf{8}$ $\left(\begin{array}{llll}604.8 & \mathrm{mg}, & 4.8 & \mathrm{mmol}\end{array}\right)$ and 1,8-diazabicyclo[5.4.0]undec-7-ene (DBU, $1.24 \mathrm{~g}, 8.16$ $\mathrm{mmol})$ in DCM $(15 \mathrm{~mL})$, under nitrogen atmosphere. The stirred reaction mixture was refluxed at $55-60{ }^{\circ} \mathrm{C}$ for $1.5 \mathrm{~h}$. After that period of time, the solution was cooled down to 0 ${ }^{\circ} \mathrm{C}$, taken up in petroleum $(100 \mathrm{~mL})$, and washed with sat. aq. $\mathrm{NaHCO}_{3}(3 \times 30 \mathrm{~mL})$, and with water $(30 \mathrm{~mL})$. The organic phase was dried $\left(\mathrm{MgSO}_{4}\right)$ and concentrated to give 9 as a pale yellow oil ( $896 \mathrm{mg}, 4.52 \mathrm{mmol}, 94 \%$ yield). This compound was used without any further purification. IR (thin film) $\bar{v}_{\max }: 3060,2960,2840$, and $1660 \mathrm{~cm}^{-1}$; ; ${ }^{1} \mathrm{H}-\mathrm{NMR}\left(60 \mathrm{MHz}, \mathrm{CDCl}_{3}\right) \delta: 0.05$ (s, 9H, $\mathrm{OSiMe}_{3}$ ), 1.80-2.30 (m, 5H, 6- $\mathrm{CH}_{2}, 7-\mathrm{CH}_{2}$ and $\mathrm{H}-4 \alpha$ ), 2.70 (bdd, $1 \mathrm{H}$, $\left.\mathrm{J}_{1}=16.5, \mathrm{~J}_{2}=5.0 \mathrm{~Hz}, \mathrm{H}-4 \beta\right), 4.40-4.70(\mathrm{~m}, 2 \mathrm{H}, \mathrm{H}-1$ and $\mathrm{H}-5), 5.10(\mathrm{~d}, 1 \mathrm{H}, \mathrm{J}=5.0 \mathrm{~Hz}, \mathrm{H}-2)$.

2-(Methoxycarbonylmethyl)-8-oxabicyclo[3.2.1]octan-3one (10a)

1.4 M MeLi in ether ( $3.4 \mathrm{~mL}, 4.76 \mathrm{mmol})$ was added to a stirred solution of $9(895 \mathrm{mg}, 4.52 \mathrm{mmol})$ in DME (20 $\mathrm{mL})$, at $-40{ }^{\circ} \mathrm{C}$ for $1.5 \mathrm{~h}$, and then a solution of methyl bromoacetate $(2.1 \mathrm{~g}, 13.73 \mathrm{mmol})$ in DME $(10 \mathrm{~mL})$ was added slowly. The resultant solution was allowed to warm up to room temperature, and stirred for further $8 \mathrm{~h}$. Water $(100 \mathrm{~mL})$ was added and the mixture was extracted with ethyl acetate $(4 \times 50 \mathrm{~mL})$. The combined organic extracts were dried $\left(\mathrm{MgSO}_{4}\right)$ and concentrated to a brown oil. This oil was chromatographed (1:1 ethyl acetate: petrol) to afford $45 \%$ (403 mg, $2.03 \mathrm{mmol}$ ) of 10a as an inseparable mixture of two isomers ( $\alpha$ and $\beta$ ) and $25 \%$ of the parent ketone 8. IR (thin film) $\bar{v}_{\max }: 2956,2886,1738,1715,1438$, 1259, 1208, 1173, and $1033 \mathrm{~cm}^{-1}$; ${ }^{1} \mathrm{H}-\mathrm{NMR}(220 \mathrm{MHz}$, $\left.\mathrm{CDCl}_{3}\right) \delta: 1.60-2.30\left(\mathrm{~m}, 4 \mathrm{H}, 6-\mathrm{CH}_{2}\right.$, and 7- $\left.\mathrm{CH}_{2}\right), 2.40-3.00$ (m, 5H, H-2, 4- $\mathrm{CH}_{2}$, and $\mathrm{CH}_{2}$ from the alkyl chain), 3.72 and 3.80 (two singlets ratio 5:1,3H, methoxy from $\beta$ and $\alpha$ isomers), 4.48-4.70 (m, $2 \mathrm{H}, \mathrm{H}-1$ and $\mathrm{H}-5)$; $\mathrm{MS} \mathrm{m} / \mathrm{z}(\%)$ : $198\left(\mathrm{M}^{+}\right), 167\left([\mathrm{M}-\mathrm{OMe}]^{+}\right), 139,126,55$.

3-(Methoxycarbonylmethyl)-8-oxabicyclo[5.3.0]dec-4-en e-2,9-dione (13)

Trimethylsilyltrifluoromethanesulfonate (TMSOTf, $2.32 \mathrm{~mL}, 12 \mathrm{mmol}$ ) was added to a stirred ice-cooled solution of keto esters $\mathbf{1 0 a} / \mathbf{1 0 b}(800 \mathrm{mg})$ and TEA $(1.95 \mathrm{~mL}, 14$ $\mathrm{mmol})$ in $\mathrm{CCl}_{4}(3 \mathrm{~mL})$. The resultant solution was stirred at room temperature for $2 \mathrm{~h}$, and then poured into an ice-cooled sat. aq. $\mathrm{NaHCO}_{3}$ solution $(25 \mathrm{~mL})$ and the product extracted into DCM $(4 \times 40 \mathrm{~mL})$. The combined organic extracts were dried $\left(\mathrm{MgSO}_{4}\right)$ and concentrated to an orange oil. This oil was purified by chromatography (1:1 ethyl ace- tate: petrol) to afford the bicyclic lactone $\mathbf{1 3}$ in very low yield $(70 \mathrm{mg}, 0.35 \mathrm{mmol})$, m.p. $149-151^{\circ} \mathrm{C}$; IR $\left(\mathrm{CHCl}_{3}\right)$ $\bar{v}_{\max }: 3020,2971,1781$ (lactone), 1717 (ester + ketone), 1516, 1459, 1370, 1290, 1151, 1046, 1016 and $788 \mathrm{~cm}^{-1}$; ${ }^{1} \mathrm{H}-\mathrm{NMR}\left(220 \mathrm{MHz}, \mathrm{CDCl}_{3}\right) \delta: 2.20-2.30(\mathrm{~m}, 1 \mathrm{H}, \mathrm{H}-6)$, $2.40\left(\right.$ dd. $\left.1 \mathrm{H}, \mathrm{J}_{10^{\prime}, 10}=16.5, \mathrm{~J}_{10^{\prime}, 1}=5.0 \mathrm{~Hz}, \mathrm{H}-10^{\prime}\right)$, 2.50-2.70 (m, 1H, H-6' ), $2.60\left(\mathrm{dd}, 1 \mathrm{H}, \mathrm{J}_{11,11}\right.$ ' $=17.5, \mathrm{~J}_{11,3}=$ $9.0 \mathrm{~Hz}, \mathrm{H}-11), 3.00\left(\mathrm{dd}, 1 \mathrm{H}, \mathrm{J}_{10,10},=16.5, \mathrm{~J}_{10,1}=8.5 \mathrm{~Hz}\right.$, $\mathrm{H}-10), 3.15$ (dd, 1H, J $1_{1}, 11=17.5, \mathrm{~J}_{11^{\prime}, 3}=4.0 \mathrm{~Hz}, \mathrm{H}-11^{\prime}$ ), 3.70-3.80 (m, 1H, H-1 ), 3.72 (s, 3H, OMe), 3.85 (ddd, $1 \mathrm{H}$, $\left.\mathrm{J}_{3,11}=9.0, \mathrm{~J}_{3,4}=7.0, \mathrm{~J}_{3,11},=4.0 \mathrm{~Hz}, \mathrm{H}-3\right), 4.95\left(\mathrm{ddd}, 1 \mathrm{H}, \mathrm{J}_{7,6}\right.$ $\left.=9.0, \mathrm{~J}_{7,1}=7.0, \mathrm{~J}_{7,6^{\prime}}=4.0 \mathrm{~Hz}, \mathrm{H}-7\right), 5.80-5.90(\mathrm{~m}, 2 \mathrm{H}, \mathrm{H}-4$ and $\mathrm{H}-5) ;{ }^{13} \mathrm{C}-\mathrm{NMR}\left(100 \mathrm{MHz}, \mathrm{CDCl}_{3}\right) \delta: 29.0,29.8,34.0$ (C-11, C-6 and C-10), 49.0 (C-1), 50.0 (C-3), 52.0 (OMe), 80.0 (C-7), 125.0 and 130.5 (C-4 and C-5), 172.0 and 175.0 (C-12 and C-9), $205.0(\mathrm{C}-2) ; \mathrm{MS} \mathrm{m} / \mathrm{z}(\%): 238.0827\left(\mathrm{M}^{+}\right.$, $\mathrm{C}_{12} \mathrm{H}_{14} \mathrm{O}_{5}$ requires 238.0837, 4), 207(7), 206(100), 188(15), 179(23), 160(18), 126(20), 94(18), 84(80), $55(69)$.

\section{4-Oxohexanoic acid (17)}

To a stirred solution of succinic an hydride (3.56 g; $35.6 \mathrm{mmol})$ in dry DCM $(30 \mathrm{~mL})$, kept under nitrogen atmosphere and at room temperature, was added $\mathrm{Et}_{3} \mathrm{Al}_{2} \mathrm{Cl}_{3}(8.9 \mathrm{~g} ; 8.15 \mathrm{mmol})$. The resultant mixture was refluxed at $60{ }^{\circ} \mathrm{C}$ for $3 \mathrm{~h}$, and then poured into an ice-cooled solution of $15 \% \mathrm{H}_{2} \mathrm{SO}_{4}(200 \mathrm{~mL})$. After 30 min the two phases were separated and aqueous layer was extracted with DCM $(5 \times 60 \mathrm{~mL})$. The combined or ganic extract was washed with brine $(50 \mathrm{~mL})$, dried over $\mathrm{MgSO}_{4}$ and concentrated under reduced pressure to leave a pale yellow oil. This oil was purified by distil lation under reduced pressure to afford the required acid 17 in $69 \%$ yield $\left(3.19 \mathrm{~g} ; 24.6 \mathrm{mmol} ; 90^{\circ} \mathrm{C} / 16 \mathrm{mmHg}\right.$ ) and a small amount $\left(5 \% 0.2 \mathrm{~g} 1.78 \mathrm{mmol} ; 65^{\circ} \mathrm{C} / 16 \mathrm{mmHg}\right)$ of compound 16. Data for 17: IR (thin film) $\bar{v}_{\max }$ : $3500-2500,1710,1420,1370,1220,1170,1120,960$ and $840 \mathrm{~cm}^{-1} ;{ }^{1} \mathrm{H}-\mathrm{NMR}\left(220 \mathrm{MHz}, \mathrm{CDCl}_{3}\right) \delta: 1.20(\mathrm{t}, 3 \mathrm{H}, \mathrm{J}=$ $\left.7.0 \mathrm{~Hz}, \mathrm{CH}_{3}\right), 2.50\left(\mathrm{q}, 2 \mathrm{H}, \mathrm{J}=7.0 \mathrm{~Hz}, \mathrm{CH}_{2}\right), 2.60-2.80(\mathrm{~m}$, $4 \mathrm{H}, \mathrm{CH}_{2} \mathrm{CH}_{2}$ ), 11.30 (bs, $1 \mathrm{H}, \mathrm{COOH}$ ); $\mathrm{MS} \mathrm{m} / \mathrm{z}(\%): 131$ $\left([\mathrm{M}+1]^{+}, 12\right), 113(100), 108(45), 73(22), 57(95), 45(30)$.

\section{Methyl 4-oxohexanoate (18)}

To a solution of the acid $\mathbf{1 7}(2.56 \mathrm{~g} ; 1.97 \mathrm{mmol})$ in dry methanol $(50 \mathrm{~mL})$, was added conc. $\mathrm{H}_{2} \mathrm{SO}_{4}(0.5 \mathrm{~mL})$. The resultant solution stirred at room temperature for $18 \mathrm{~h}$, before addition of an aqueous solution of $\mathrm{NaHCO}_{3}$ (sat. 10 $\mathrm{mL})$. The aqueous layer was extracted with DCM $(3 \times 30$ $\mathrm{mL}$ ). The combined organic extracts were dried over $\mathrm{MgSO}_{4}$ and concentrated under reduced pressure to leave the required ester 18 in $88 \%$ yield $(2.50 \mathrm{~g} ; 17.4 \mathrm{mmol})$. No further purification was carried out. IR (thin film) $\bar{v}_{\max }$ : 
2960, 2920, 1740, 1715, 1440, 1420, 1360, 1210, 1170, 1110 and $840 \mathrm{~cm}^{-1} ;{ }^{1} \mathrm{H}-\mathrm{NMR}\left(220 \mathrm{MHz}, \mathrm{CDCl}_{3}\right) \delta: 1.20(\mathrm{t}$, $3 \mathrm{H}, \mathrm{J}=7 \mathrm{~Hz}, \mathrm{CH}_{3}$ ), 2.50 (q, 2H, J = $7 \mathrm{~Hz}, \mathrm{CH}_{2}$ ), 2.65 (bt, $2 \mathrm{H}, \mathrm{J}=7 \mathrm{~Hz}, \mathrm{CH}_{2}$ ), 2.75 (bt, $2 \mathrm{H}, \mathrm{J}=7 \mathrm{~Hz}, \mathrm{CH}_{2}$ ), 3.68 (s, 3H, $\left.\mathrm{OCH}_{3}\right)$.

\section{Methyl 3,5-dibromo-4-oxohexanoate (19)}

Bromine (2.0 g; $12.5 \mathrm{mmol})$ was added dropwise to a stirred ice-cooled solution of ketoester 18 (0.9 g; 6.25 $\mathrm{mmol})$ in ether $(10 \mathrm{~mL})$ and $\mathrm{HBr}$ aq. $(48 \% ; 5 \mathrm{~mL})$. After 72 $\mathrm{h}$ stirring at room temperature, diethyl ether $(80 \mathrm{~mL})$ and an aqueous solution of $\mathrm{Na}_{2} \mathrm{~S}_{2} \mathrm{O}_{5}(10 \%, 30 \mathrm{~mL})$ were added. The two phases were separated and the organic layer was washed with brine $(2 \times 30 \mathrm{~mL})$, dried over $\mathrm{MgSO}_{4}$ and concentrated under reduced pressure to leave a crude product as an yellow oil. This oil was purified by column chromatography (petroleum/ether, 2:1) to produce the dibromoketoester 19, $42 \%$ yield ( $800 \mathrm{mg} ; 2.65 \mathrm{mmol}$ ) as a pale yellow oil. IR (thin film) $\bar{v}_{\text {max }}: 3010,2980,2960,2880$, 1740, 1440, 1370, 1210, 920 and $860 \mathrm{~cm}^{-1 ; 1} \mathrm{H}-\mathrm{NMR}$ (220 $\left.\mathrm{MHz}, \mathrm{CDCl}_{3}\right) \delta: 1.85\left(\mathrm{~d}, 3 \mathrm{H}, \mathrm{J}=6.5 \mathrm{~Hz}, \mathrm{CH}_{3}\right), 3.00-3.20$ $\left(\mathrm{m}, 2 \mathrm{H}, \mathrm{CH}_{2}\right), 3.70\left(\mathrm{~s}, 3 \mathrm{H}, \mathrm{OCH}_{3}\right), 5.05(\mathrm{q}, 1 \mathrm{H}, \mathrm{J}=6.5 \mathrm{~Hz}$, $\mathrm{CHBr}), 5.20$ (t, 1H, J = 6.5 Hz, CHBr).

\section{2-(Methoxycarbonylmethyl)-4-methyl-8-oxabicyclo[3.2.1 Joct-6-en-3-one (20)}

A $100 \mathrm{~mL}$ round botton flask was fitted with a $10 \mathrm{~mL}$ dropping funnel and dry acetonitrile $(20 \mathrm{~mL})$. Dry NaI (1.99 g, $13.2 \mathrm{mmol}$ ) was added with vigorous stirring under a slow stream of nitrogen. Then powdered copper $(0.61 \mathrm{~g}$, $10.5 \mathrm{mmol}$ ) was added, followed by furan $(1.89 \mathrm{~mL}, 26$ mmol). A solution of dibromoketone 19 (800 mg, 2.64 $\mathrm{mmol})$ in dry acetonitrile $(5 \mathrm{~mL})$ was added, via a dropping funnel, during $10 \mathrm{~min}$, at $0{ }^{\circ} \mathrm{C}$. The reaction mixture was allowed to warm up to room temperature and stirred for $16 \mathrm{~h}$. After that time the flask was cooled to $0{ }^{\circ} \mathrm{C}$ and dichloromethane $(30 \mathrm{~mL})$ was added. The resultant mixture was then poured into a conical flask containing water $(30 \mathrm{~mL})$ and crushed ice $(30 \mathrm{~mL})$, and it was thoroughly stirred to allow the precipitation of copper salts. After filtration through a Celite pad, the mother liquor was washed with aqueous $\mathrm{NH}_{3}$ solution ( $\left.45 \% \mathrm{v} / \mathrm{v}, 3 \times 20 \mathrm{~mL}\right)$, brine $(20 \mathrm{~mL})$, dried over $\mathrm{MgSO}_{4}$, and concentrated to a pale yellow oil. Further purification by flash chromatography (2:3 petrol:ether) gave $27 \%$ (150 mg, $0.7 \mathrm{mmol})$ overall yield of the required product $\mathbf{2 0}$ as an isomeric mixture, in a ratio of 4:1 ( $\alpha \alpha: \beta \beta)$. Further purification by column chromatography afforded a pure sample of the major $\alpha, \alpha$-isomer. Data for 20a: IR (thin film) $\bar{v}_{\max }$ : 3082, 2952, 1742, 1714, 1440, 1373, 1233, 1176, 1060, 924 and $819 \mathrm{~cm}^{-1}$; ${ }^{1} \mathrm{H}-\mathrm{NMR}(220$ $\left.\mathrm{MHz} \mathrm{CDCl}_{3}\right) \delta: 0.96\left(\mathrm{~d}, 3 \mathrm{H}, \mathrm{J}=6.5 \mathrm{~Hz}, \mathrm{CH}_{3}\right), 2.02(\mathrm{dd}, 1 \mathrm{H}$, $\left.\mathrm{J}_{1}=16.8, \mathrm{~J}_{2}=7.0 \mathrm{~Hz}, \mathrm{H}-8^{\prime}\right), 2.70\left(\mathrm{dd}, 1 \mathrm{H}, \mathrm{J}_{1}=16.8, \mathrm{~J}_{2}=7.0\right.$ $\mathrm{Hz}, \mathrm{H}-8), 2.88$ (dq, 1H, $\left.\mathrm{J}_{1}=7.0, \mathrm{~J}_{2}=5.0 \mathrm{~Hz}, \mathrm{H}-4\right), 3.30$ (dt, $\left.1 \mathrm{H}, \mathrm{J}_{1}=7.0, \mathrm{~J}_{2}=4.0 \mathrm{~Hz}, \mathrm{H}-2\right), 3.71\left(\mathrm{~s}, 3 \mathrm{H}, \mathrm{OCH}_{3}\right), 4.89(\mathrm{dd}$, $\left.1 \mathrm{H}, \mathrm{J}_{1}=4.0, \mathrm{~J}_{2}=1.8 \mathrm{~Hz}, \mathrm{H}-5\right), 4.98\left(\mathrm{dd}, 1 \mathrm{H}, \mathrm{J}_{1}=4.0, \mathrm{~J}_{2}=\right.$ $1.8 \mathrm{~Hz}, \mathrm{H}-1), 6.32$ and $6.38\left(2 \mathrm{x} \mathrm{dd}, 2 \mathrm{H}, \mathrm{J}_{1}=6.0, \mathrm{~J}_{2}=1.8 \mathrm{~Hz}\right.$, $\mathrm{H}-6$ and $\mathrm{H}-7)$; $\mathrm{MS} \mathrm{m} / \mathrm{z}(\%): 211.0970\left([\mathrm{M}+1]^{+}, \mathrm{C}_{11} \mathrm{H}_{15} \mathrm{O}_{4}\right.$ requires 211.0961, 12), 178(100), 151(15), 113(18), 94(13), 81(22), 67(5), 55(20).

2-(Methoxycarbonylmethyl)-4-methyl-8-oxabicyclo[3.2.1 Joctan-3-one (21)

The ketoester 20a (504 mg, $2.4 \mathrm{mmol}$ ) was dissolved in ethyl acetate $(25 \mathrm{~mL})$, in a Parr hydrogenation bottle, and $10 \% \mathrm{Pd}-\mathrm{C}(70 \mathrm{mg})$ was added as a catalyst. The reaction was carried out under $3.0 \times 10^{5} \mathrm{~Pa}$ of hydrogen pressure for $22 \mathrm{~h}$. The catalyst was filtered off through a Celite pad and the solvent removed under reduced pressure to leave the required product $\mathbf{2 1}$ as a pale yellow oil in quantitative yield. No further purification was necessary. IR (thin film) $\bar{v}_{\max }$ : 2953, 2840, 1738, 1711, 1440, 1360, 1270, 1200, 1180, 1160, 1050, 950 and $890 \mathrm{~cm}^{-1} ;{ }^{1} \mathrm{H}-\mathrm{NMR}(220 \mathrm{MHz}$, $\left.\mathrm{CDCl}_{3}\right) \delta: 0.96\left(\mathrm{~d}, 3 \mathrm{H}, \mathrm{J}=6.5 \mathrm{~Hz}, \mathrm{CH}_{3}\right), 1.50-1.90(\mathrm{~m}, 4 \mathrm{H}$, $\mathrm{CH}_{2} \mathrm{CH}_{2}$ ), 2.03 (dd, $1 \mathrm{H}, \mathrm{J}_{1}=16.8, \mathrm{~J}_{2}=7.0 \mathrm{~Hz}, \mathrm{H}-8$ '), 2.78 (dd, $\left.1 \mathrm{H}, \mathrm{J}_{1}=16.8, \mathrm{~J}_{2}=7.0 \mathrm{~Hz}, \mathrm{H}-8\right)$ 2.80-2.90 (m 1H, H-2), 3.25-3.35 (m, 1H, H-4), 3.70 (s, 3H, $\left.\mathrm{OCH}_{3}\right), 4.45-4.60$ (m, $2 \mathrm{H}, \mathrm{H}-1$ and $\mathrm{H}-5)$

7-Methyl-5,11-dioxatricyclo[6.2.1.0 2,6 ]und-9-en-4-one (22) and 7-Methyl-5,11-dioxatricyclo[6.2.1.0 2,6 ] undecan-4-one (23)

To a stirred solution of ketone $\mathbf{2 0 a}(210 \mathrm{mg}, 1 \mathrm{mmol})$ in methanol $(10 \mathrm{~mL})$ was added $\mathrm{NaBH}_{4}(80 \mathrm{mg}, 2 \mathrm{mmol})$. After stirring at room temperature for $4 \mathrm{~h}$, the reaction was quenched with water $(20 \mathrm{~mL})$, and the product extracted with DCM $(3 \times 30 \mathrm{~mL})$. The organic extract was dried over $\mathrm{MgSO}_{4}$ and concentrated under reduced pressure to an yellow oil. This oil was purified by flash chromatography on silica gel (petrol:ether, 1:8) to afford the required lactone 22 in 59\% yield as a white solid (210 mg, $1.2 \mathrm{mmol})$. This product was recrystallyzed from DCM:ether. A similar procedure was used to prepare lactone $\mathbf{2 3}$ from ketoester 21. Data for 22: m.p. $121-122{ }^{\circ} \mathrm{C}$. white solid. IR $\left(\mathrm{CHCl}_{3}\right)$ $\bar{v}_{\max }: 3083,2972,2930,2887,1758,1598,1460,1424$, 1369, 1200, 1109, 1049, 989 and $816 \mathrm{~cm}^{-1} ;{ }^{1} \mathrm{H}-\mathrm{NMR}(400$ $\left.\mathrm{MHz}, \mathrm{CDCl}_{3}\right) \delta: 1.05\left(\mathrm{~d}, 3 \mathrm{H}, \mathrm{J}=7.0 \mathrm{~Hz}, \mathrm{CH}_{3}\right), 2.05(\mathrm{dd}$, $1 \mathrm{H}, \mathrm{J}=16.9, \mathrm{H}-3), 2.20\left(\mathrm{ddd}, 1 \mathrm{H}, \mathrm{J}_{1}=7.0, \mathrm{~J}_{2}=5.7, \mathrm{~J}_{3}=4.2\right.$ Hz, H-7), 2.57 (dd, 1H, J $=16.9, \mathbf{J}_{2}=9.1 \mathrm{~Hz}, \mathrm{H}-3$ '), 2.80 (bdt, $\left.1 \mathrm{H}, \mathrm{J}_{1}=9.1, \mathrm{~J}_{2} \cong \mathrm{J}_{3} \cong 5.7 \mathrm{~Hz}, \mathrm{H}-2\right), 4.45(\mathrm{~m}, 1 \mathrm{H}, \mathrm{H}-8)$, 4.53-4.60 (m, 2H, H-1 and H-6), $6.16\left(\mathrm{dd}, 1 \mathrm{H}, \mathrm{J}_{1}=6.2, \mathrm{~J}_{2}=\right.$ $1.7 \mathrm{~Hz}, \mathrm{H}-10$ ), 6.38 (dd, 1H, J $=6.2, \mathrm{~J}_{2}=1.8 \mathrm{~Hz}, \mathrm{H}-9$ ); ${ }^{13} \mathrm{C}-\mathrm{NMR}\left(100 \mathrm{MHz}, \mathrm{CDCl}_{3}\right) \delta: 12.45\left(\mathrm{CH}_{3}\right), 32.02(\mathrm{C}-3)$, 32.73/35.28(C-2/C-7) 79.04/80.75(C-1/C-8), 81.58(C-6), 130.74/136.18(C-9/C-10), 176.03(C-4); MS m/z(\%): $180.0786\left(\mathrm{M}^{+}, \mathrm{C}_{10} \mathrm{H}_{12} \mathrm{O}_{3}\right.$ requires 180.0786, (15), 121(3), 
95(90), 91(8), 85(18), 81(100), 68(35), 67(45), 55(35); $\mathrm{C}_{10} \mathrm{H}_{12} \mathrm{O}_{3}$ requires $\mathrm{C} 66.65$ and $\mathrm{H} 6.71 \%$; found $\mathrm{C} 66.64$ and $\mathrm{H}$ 6.75\%; Data for 23: m.p. $78-79^{\circ} \mathrm{C}$; IR $\left(\mathrm{CHCl}_{3}\right) v_{\max }$ : 3005, 2980, 2880, 1765, 1480, 1220, 1180, 980 and 880 $\mathrm{cm}^{-1} ;{ }^{1} \mathrm{H}-\mathrm{NMR}\left(400 \mathrm{MHz}, \mathrm{CDCl}_{3}\right) \delta: 1.08(\mathrm{~d}, 3 \mathrm{H}, \mathrm{J}=7.0$ $\left.\mathrm{Hz}, \mathrm{CH}_{3}\right), 1.60-2.00\left(\mathrm{~m}, 4 \mathrm{H}, \mathrm{CH}_{2} \mathrm{CH}_{2}\right), 2.09-2.20(\mathrm{~m}, 1 \mathrm{H}$, $\mathrm{H}-6), 2.18(\mathrm{~d}, 1 \mathrm{H}, \mathrm{J}=17.0 \mathrm{~Hz}, \mathrm{H}-3), 2.65\left(\mathrm{dd}, 1 \mathrm{H}, \mathrm{J}_{1}=17.0\right.$, $\mathrm{J}_{2}=8.4 \mathrm{~Hz}, \mathrm{H}-3$ ') $2.70-2.80(\mathrm{~m}, 1 \mathrm{H}, \mathrm{H}-2), 4.05-4.15$ (m, $1 \mathrm{H}, \mathrm{H}-8), 4.22\left(\mathrm{bt}, 1 \mathrm{H}, \mathrm{J}_{1}=6.1 \mathrm{~Hz}, \mathrm{H}-1\right), 4.41(\mathrm{t}, 1 \mathrm{H}, \mathrm{J}=4.7$ $\mathrm{Hz}, \mathrm{H}-6) ;{ }^{13} \mathrm{C}-\mathrm{NMR}\left(100 \mathrm{MHz}, \mathrm{CDCl}_{3}\right) \delta: 12.77\left(\mathrm{CH}_{3}\right)$, 23.06/24.58 (C-9/C-10), 32.94 (C-3), 36.58/37.75 (C-2/C-7), 74.84/76.93 (C-1/C-8), 80.37 (C-6), 176.43 (C-4); MS m/z(\%): $182.0943\left(\mathrm{M}^{+}, \mathrm{C}_{10} \mathrm{H}_{14} \mathrm{O}_{3}\right.$ requires 182.0943, (33), 165(20), 124(20), 98(88), 80(75), 69(100), 55(65).; $\mathrm{C}_{10} \mathrm{H}_{14} \mathrm{O}_{3}$ requires $\mathrm{C} 65.92$ and $\mathrm{H} 7.74 \%$; found $\mathrm{C}$ 65.89 and $\mathrm{H} 7.75 \%$.

\section{Bioassays}

The bioassays were carried out according to the method of Einhelling et al. ${ }^{23}$ with seeds of Sorghum bicolor. Dichloromethane solutions of compounds 7, 13, 17, 20a, 22 and $\mathbf{2 3}$ were prepared at concentrations of 100 and 1000 ppm.

Assays were conducted in a $100 \times 15 \mathrm{~mm}$ glass Petri dishes lined with 1 sheet of Whatman No. 1 filter paper and sealed with parafilm. To each dish was added $2 \mathrm{~mL}$ of each solution and the solvent was evaporated before addition of $2 \mathrm{~mL}$ of water followed by 20 seeds of Sorghum bicolor. Assays were carried out at $25^{\circ} \mathrm{C}$ under artificial fluorescent light $(8 \times 40 \mathrm{~W})$ in a incubator during three days, after which germination was scored and the radicle lenth was measured. Seeds were considered to be germinated if a radicle protuded at least $1 \mathrm{~mm}$. A controling experiment was carried out under the same conditions described, using only water. Each bioassay was replicated 5 times in a complete randomized design.

\section{Results and Dicussion}

\section{Synthesis}

The oxabicyclic ketone 7, has already been transformed into a number of natural products and their analogues ${ }^{8,9}$, and we thought to explore further its chemistry by using it as starting material for the synthesis of sesquiterpene lactone $4\left(\mathrm{R}_{1}=\mathrm{H}\right.$ or $\left.\mathrm{CH}_{3}\right)$, according to the strategy shown on Scheme 1 .

The ketone 7 was prepared on a large scale using Sato and Noyori's methodology ${ }^{10}$. Catalytic hydrogenation of 7 using 10\% Pd-C afforded the oxabicyclic ketone 8 in almost quantitative yield. The enol silyl ether $\mathbf{9}$ was prepared in about $95 \%$ yield using trimethylsilylchloride (TMSCl) in the presence 1,8-diazabicyclo[5.4.0]undec-7-ene (DBU). The almost quantitative conversion of the parent ketone 8 into the required enol ether 9 was confirmed by the virtual disappearance of the carbonyl stretching at around $1715 \mathrm{~cm}^{-1}$ (in the infrared spectrum) with concomitant appearance of a very strong band at $\sim 1640 \mathrm{~cm}^{-1}$ corresponding to the enol trimethylsilyl group.

The enol ether 9 was treated with methyl lithium and the enolate formed was trapped with methyl bromoacetate (Scheme 2). It was observed that when the enolate was generated at $-78{ }^{\circ} \mathrm{C} / 1.5 \mathrm{~h}$, the reaction was incomplete resulting in $29 \%$ recovery of the starting enol ether. Raising the temperature to $-40{ }^{\circ} \mathrm{C}$ resulted in complete transformation of 9 into the corresponding enolate. In general, typical overall yields for this alkylation was $30-45 \%$ for the monoalkylated compound 10a, $15-20 \%$ for the corresponding dialkylated methyl ester $\mathbf{1 0 b}$ and $20-30 \%$ recovery of the starting ketone 8 . It was found that separation of the monoalkylated 10a from the dialkylated methyl ester $\mathbf{1 0 b}$ was extremely difficult, and $10 \mathrm{~b}$ was not obtained in a pure form. Some reactions were carried out with 10a con-
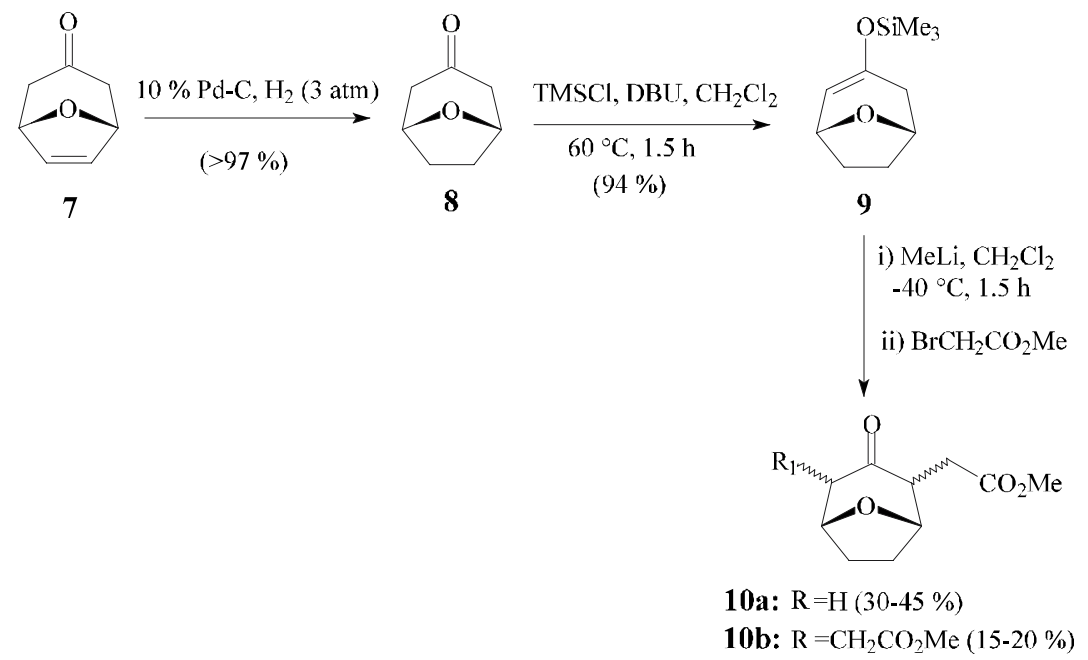

Scheme 2. 
taminated with $15-20 \%$ of $\mathbf{1 0 b}$, as estimated by $220 \mathrm{MHz}$ ${ }^{1} \mathrm{H}-\mathrm{NMR}$.

Although a high degree of exo-stereoselectivity for this alkylation has been claimed ${ }^{11}$, the complexity of the signals for $\mathrm{H}-1$ and $\mathrm{H}-5$ between $\delta 4.50$ and $\delta 4.70$ associated with two signals for methoxy group at $\delta 3.72$ and $\delta 3.80$ (ratio $5: 1)$ showed that a considerable amount $(20 \%)$ of the endo-alkylated product was formed (the sample analysed was not contaminated with $\mathbf{1 0 b}$ as judged by the mass spectrum).

It was envisaged that the transformation of 10a into lactone 12 could be achieved via an intermediate like 11, formed by the cleavage of the ether bridge (Scheme 3 ).

The ketoester 10a was then submitted to a treatment with the following reagents in order to accomplish the ether cleavage: $\mathrm{HBr}$ (aq. 48\%), hexadecyltributylphosphonium bromide, $48 \mathrm{~h}, 60^{\circ} \mathrm{C}^{12} ; \mathrm{BF}_{3}, \mathrm{KI}, \mathrm{CHCl}_{3}, 144 \mathrm{~h}, 55^{\circ} \mathrm{C}^{13,14}$; $\mathrm{Me}_{6} \mathrm{Si}_{2}, \mathrm{I}_{2}, \mathrm{C}_{6} \mathrm{H}_{6}, 65^{\circ} \mathrm{C}, 72 \mathrm{~h}$, dark ${ }^{15,16} ; \mathrm{Me}_{3} \mathrm{SiCl}, \mathrm{NaI}$, $\mathrm{CH}_{3} \mathrm{CN}, 70{ }^{\circ} \mathrm{C} 72 \mathrm{~h}$, dark ${ }^{17} ; t$-BuMe $2 \mathrm{SiCl}, \mathrm{NaI}, \mathrm{CH}_{3} \mathrm{CN}, 65$ ${ }^{\circ} \mathrm{C} 120 \mathrm{~h}$, dark ${ }^{18}$; $\mathrm{Me}_{2} \mathrm{BBr}$, TEA, DCM, $0{ }^{\circ} \mathrm{C}, 4 \mathrm{~h}^{19}$. In all these attempts no reaction or partial decomposition of the starting material, accompained by the formation of several compounds was observed as judged by TLC analysis.

Another attempt to produce lactone $\mathbf{1 2}$ was made by treating compound $10 a$ with trimethylsilyltrifluoromethanesulfonate (TMSOTf) and triethylamine (TEA) ${ }^{20}$, for two hours at room temperature. In this case all the starting material was consumed and a very complex mixture was formed. However when a mixture of $\mathbf{1 0 a + 1 0 b}$ was treated with TMSOTf/TEA, the only product isolated was the lactone $\mathbf{1 3}$ (Scheme 4).

The structure of the lactone 13 was deduced by spectroscopic means. In the high resolution mass spectrum, there was a peak at $\mathrm{m} / \mathrm{z} 238.0827$ corresponding to the proposed formula $\mathrm{C}_{12} \mathrm{H}_{14} \mathrm{O}_{5}$. The infrared spectrum showed a very strong absorption at $1781 \mathrm{~cm}^{-1}$ due to the $\gamma$-butyrolactone, and another band at $1717 \mathrm{~cm}^{-1}$ for the ketone superimposed with the ester group. Special features in the ${ }^{13} \mathrm{C}-\mathrm{NMR}$ spectrum are the absorptions at $\delta 172,175$ (lactone and ester), and $\delta 195$ (ketone). Signals corresponding to three $\mathrm{CH}_{2}$, one $\mathrm{CH}_{3}$, and five $\mathrm{CH}$ were observed. The $220 \mathrm{MHz}$ ${ }^{1} \mathrm{H}$-NMR spectrum showed a singlet at $\delta 3.72$ for the methoxy group, and a multiplet at $\delta 5.80-5.90$ for alkene protons (Fig. 1).

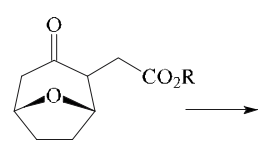

$10 \mathbf{a}$

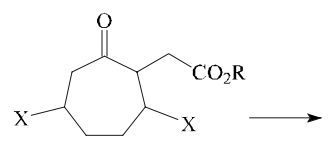

11

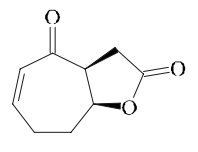

12
Scheme 3

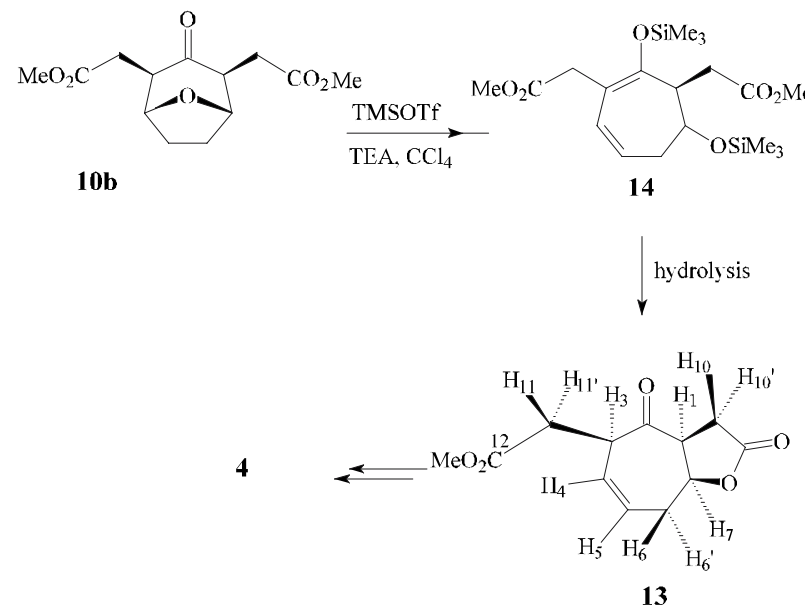

Scheme 4.

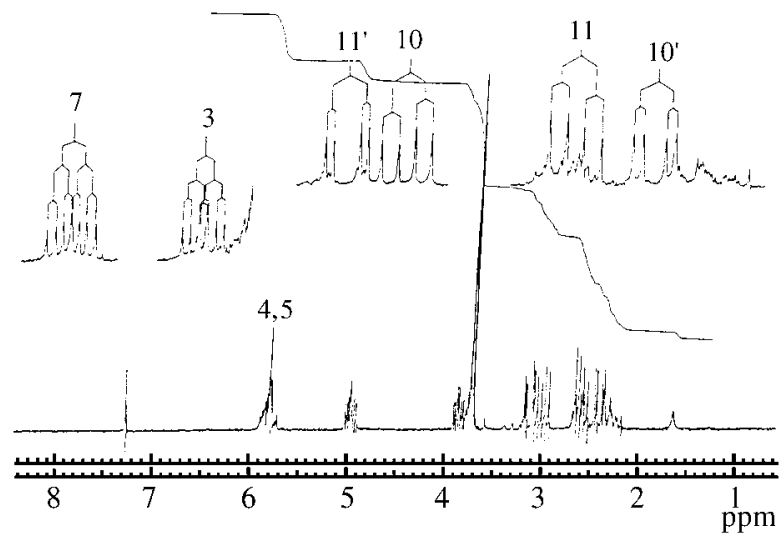

Figure 1. $220 \mathrm{MHz}{ }^{1} \mathrm{H}-\mathrm{NMR}$ spectrum of the compound [13].

The formation of lactone $\mathbf{1 3}$ probably involves the intermediate $\mathbf{1 4}^{18}$, and it shows the feasibility of our initial synthetic proposal (Scheme 1).

The formation of a complex mixture of products from this reaction is probably due to the fact that keto ester 10a was a mixture of $\alpha$ and $\beta$-alkyl isomers and also because the cleavage of the ether bridge was not regioselective. A further investigation on the preparation of the $\mathbf{1 0 b}$ and its reaction under the conditions described should be carried out, since one can envisage the transformation of lactone 13 into a pseudoguaianolide skeleton 4 .

Due to the problems with the stereoselective monoalkylation of 8 and purification of $\mathbf{1 0 a}$, an alternative route leading to lactones $\mathbf{4}$ and $\mathbf{6}$ was investigated (Schemes 5 and 6).

Succinic anhydride was converted into the keto acid $\mathbf{1 7}$ in $69 \%$ yield $^{21}$. After methylation with $\mathrm{CH}_{3} \mathrm{OH} / \mathrm{H}_{2} \mathrm{SO}_{4}$, the ester 18 formed was brominated with $\mathrm{Br}_{2} / \mathrm{HBr}$ to afford the required dibromoketone $\mathbf{1 9}$ in $42 \%$ yield.

The cycloaddition between the dibromoketoester 19 and furan was carried out in the presence of $\mathrm{Cu} / \mathrm{NaI}$. The re- 


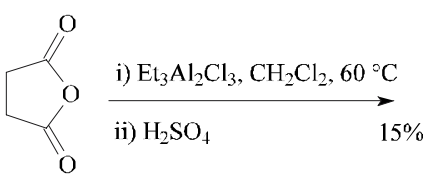

15

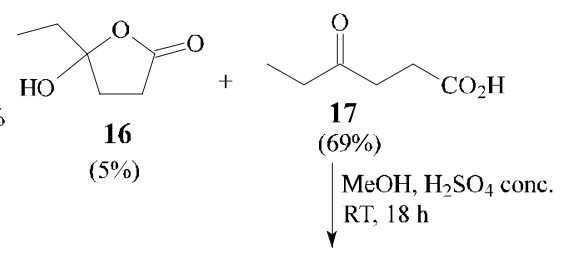

RT, $18 \mathrm{~h}$

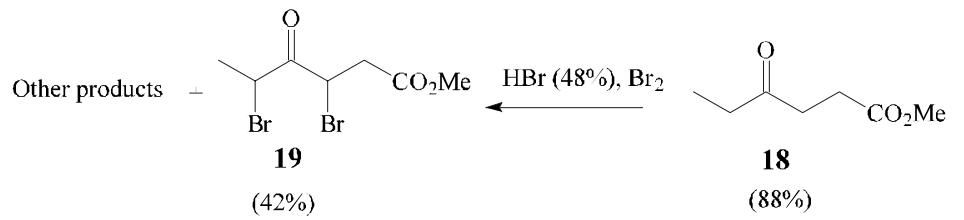

$(42 \%)$

$\mathrm{Nal} / \mathrm{Cu}$

Furan, $\mathrm{CH}_{3} \mathrm{CN}$

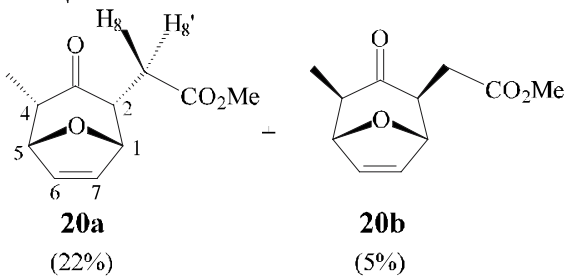

Scheme 5.

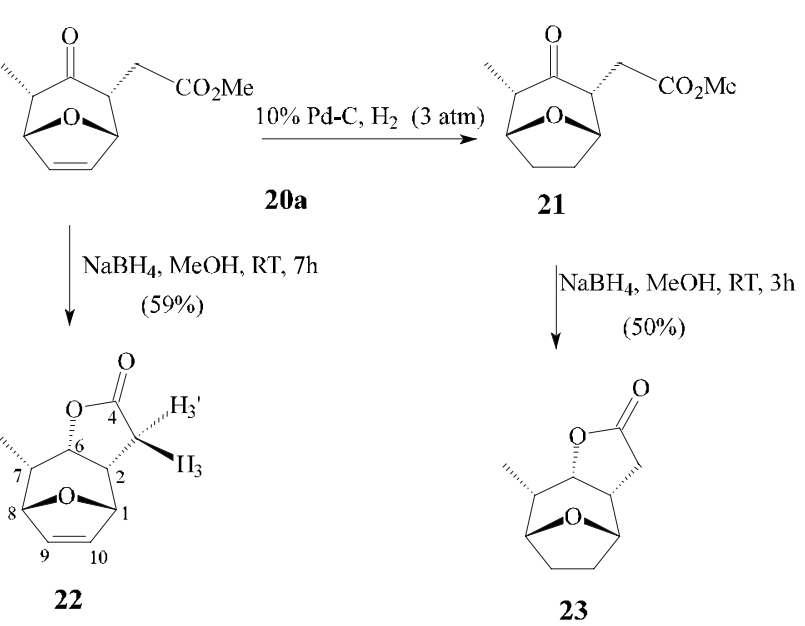

Scheme 6

quired cycloadduct $\mathbf{2 0}$ was formed in $27 \%$ yield, and the ratio between $\alpha \alpha$ - and $\beta \beta$-isomers was around $4: 1$.

In order to accomplish the strategy presented on route 1, compound 20b was required, and since this was the minor isomer formed, we used the major isomer 20a to follow the synthesis according to route 2 (Scheme 1).

The bicyclic ketone $\mathbf{2 0 a}$ was treated with $\mathrm{NaBH}_{4} / \mathrm{MeOH}$ and the intermediate formed by the reduction of the keto group reacted in a intramolecular fashion with the carbomethoxy group resulting in the formation of lactone 22 in $59 \%$ yield (Scheme 6).

The hydrogenation of the oxabicyclo $\mathbf{2 0 a}$ followed by similar treatment with $\mathrm{NaBH}_{4} / \mathrm{MeOH}$ led to the isolation of the lactone $\mathbf{2 3}$ in $50 \%$ yield.
Work is know in progress to transform compounds 22 and $\mathbf{2 3}$ in to more complex and functionalized lactones.

\section{Herbicidal Activity}

The discovery of new herbicides usually involves the following approaches: i) the rational design of specific inhibitors of key metabolic processes; ii) analogue synthesis of compounds with known herbicidal activity and iii) the random screening of new chemicals.

Although in this work we planed to make use of strategy ii), by developing a synthetic route for the preparation of several sesquiterpene lactones, having an $\alpha, \beta$-unsaturated carbonyl group, we decided to carry out a random screening on several synthetic intermediates (strategy iii).

For this screening the in vivo effect of compounds $7, \mathbf{1 3}$, 17, 20a, 22 and 23 on the germination and radicle growth of Sorghum bicolor was evaluated according to the methodology proposed by Enhelling et $a l^{23}$. Two concentrations (100 and $1000 \mathrm{ppm}$ ) of each compound were tested, since it has already been shown that some compounds exhibited both stimulatory and inhibitory effects on seedling growth, depending on the concentration ${ }^{24}$.

Figure 2 shows the radicle lenth ( $\mathrm{mm}$ ) of Sorghum after 3 days incubation at $25{ }^{\circ} \mathrm{C}$ and the percentage of radicle growth (inhibition or stimulation) in relation to the control is presented in Table 1. At $100 \mathrm{ppm}$ all compounds showed a condiderable inhibitory effect on the radicle growth, specially the ketoacid $\mathbf{1 7}$, that caused a $80 \%$ inhibition. As compound $\mathbf{1 7}$ showed a remarkably different effect on plant development at lower and higher concentration ${ }^{24}$, and since it can be easily prepared, it becames an interesting 
Table 1. Germination and radicle growth inhibition of Sorghum bicolor by several synthetic compounds after 3 days, incubation at $25{ }^{\circ} \mathrm{C}$.

\begin{tabular}{lccccccc}
\hline & \multicolumn{3}{c}{ Inhibition $(\% \text { control })^{(\mathrm{a})}$} & & \multicolumn{2}{c}{ Germination (\% control) } \\
\cline { 2 - 4 } \cline { 7 - 8 } Compound & $100 \mathrm{ppm}$ & \multicolumn{1}{c}{$1000 \mathrm{ppm}$} & & $100 \mathrm{ppm}$ & $1000 \mathrm{ppm}$ \\
\hline 7 & 1.0 & 9.5 & 34.0 & 5.1 & & 95 & 94 \\
13 & -33.0 & 2.7 & 29.0 & 5.3 & & 95 & 93 \\
17 & -35.0 & 7.2 & 80.2 & 1.1 & & 92 & 40 \\
$20 \mathrm{a}$ & $26.2 \pm 2.8$ & 45.4 & 6.1 & & 97 & 97 \\
22 & 26.0 & 4.8 & $40.6 \pm 3.8$ & & 98 & 96 \\
23 & 43.6 & 5.4 & 7.6 & 8.8 & & 96 & 92 \\
\hline
\end{tabular}

${ }^{\mathrm{a}} \mathrm{Negative} \mathrm{values} \mathrm{correspond} \mathrm{to} \mathrm{radicle} \mathrm{growth} \mathrm{induction.}$

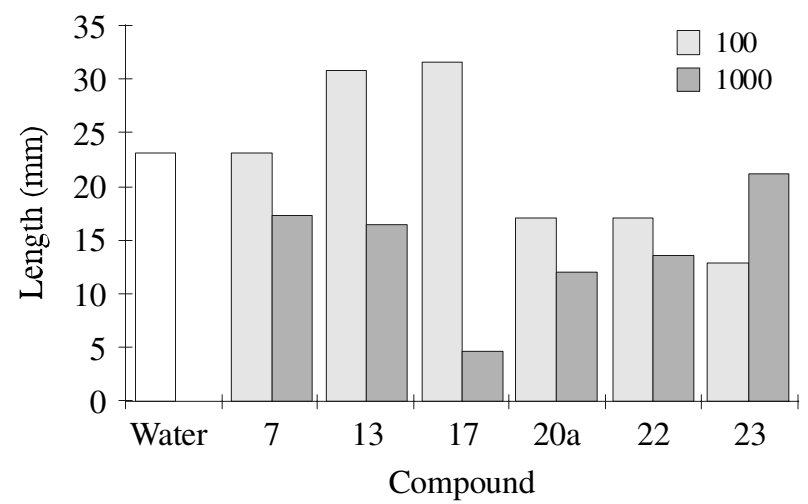

Figure 2. Root growth of Sorghum bicolor after exposure to various compounds (100 ppm and $1000 \mathrm{ppm}$ ) and water, after 3 days incubation at $25{ }^{\circ} \mathrm{C}$.

starting material for the preparation of other products for biological evaluation. Although the lactone $\mathbf{1 3}$ showed a similar effect on radicle growth as $\mathbf{1 7}$, its preparation is more laborious and this makes further biological evaluation less appealing. Compound $\mathbf{7}$ showed no clear effect at $100 \mathrm{ppm}$ and $34 \%$ inhibition at a $1000 \mathrm{ppm}$.

Compound 20a (at $100 \mathrm{ppm}$ ) was 26 times more active than its simple analogue 7 , and this effect can be attributed to the presence of the substituents at the 2 and 4 positions.

In view of these results and due to the versatility of the $[3+4]$ cycloaddition methodology used ${ }^{25}$ for the preparation of compounds 7 and $\mathbf{2 0 a}$, the synthesis of other oxabicyclic compounds like 7 having different substituents at various positions is now our next goal. Also an investigation of the herbicidal selectivity of the compounds already discussed towards a wide range of crops and weeds is underway and will be published elsewhere.

\section{Acknowledgments}

We thank the Brazilian Agencies Conselho Nacional de Desenvolvimento Científico e Tecnológico (CNPq), Coordenação de Aperfeiçoamento de Pessoal de Nível Su- perior (CAPES) and Fundação de Amparo à Pesquisa do Estado de Minas Gerais (FAPEMIG) for financial support.

\section{References}

1. Picman, A.K. Bioch. Syst. Ecol. 1986, 14, 255.

2. Fraga, B.M. Nat. Prod. Rep. 1991, 8, 515.

3. Macias, F.A.; Galindo, J.G.G.; Massanet, G.M. Phytochemistry 1992, 31, 1967.

4. Fischer, N.H.; Weidenhamer, J.D.; Riopel, J.L.; Quijans, L.; Menelaou, M.A. Phytochemistry 1990, 29, 1479.

5. Fischer, N.H. In The Science of Allelopathy. John Wiley; New York, 1986.

6. Fischer, N.H.; Weidenhamer, J.D.; Bradow, J.M. J. Chem. Ecol. 1989, 15, 1785.

7. Demuner, A.J. Síntese de substâncias reguladoras do crescimento de plantas e de substâncias com atividade anti-inflamatória, D.S. Thesis (Departamento de Química, Universidade Federal de Minas Gerais, Belo Horizonte, 1996).

8. Barbosa, L.C.A.; Mann, J. J. Chem. Soc. Perkin Trans. $1992,1,337$.

9. Hoffmann, H.M.R. Angew. Chem. Int. Ed. Engl 1984, 23, 1. 10. Sato, T.; Noyori, R. Bull. Chem. Soc. Jpn 1978, 51, 2745.

11. Bowers, K.G.; Mann, J.; Markson, A.J. J. Chem. Res. (S) 1986, 424.

12. Bhatt, M.V.; Kulkarni, S.V. Synthesis 1983, 249.

13. Mandall, A.K.; Soni, N.R.; Ratnan, K.R. Synthesis 1985, 274.

14. Yada, V.K.; Faliis, A.G. J. Org. Chem. 1986, 51, 3372.

15. Sakarai, H.; Shirahata, A.; Sasaki, K.; Hosami, A. Synthesis 1979, 740.

16. Olah, G.A.; Narang, S.C.; Gupta, G.B.; Malhotra, R. Angew. Chem. Int. Ed. Engl. 1979, 18, 612.

17. Olah, G.A.; Narang, S.C.; Gupta, G.B.; Malhotra, R. J. Org. Chem. 1979, 44, 1249.

18. Nystrom, J.E.; McConna, T.D.; Helquist, P.; Amouroux, R. Synthesis 1988, 56. 
19. Guindon, Y.; Yoakin, C.; Morton, H.E. Tetrahedron Lett. 1983, 24, 2969.

20. Föhlisch, B.; Sendelbach, S.; Bauer, H. Liebigs Ann. Chem. 1987, 1.

21. Reinheckel, H.; Haage, K. Angew. Chem. Int. Ed. Engl. 1966, 5, 511.

22. Cobb, A. In Herbicides and Plant Physiology; Chapman \& Hall; London, 1992.
23.Einhelling, F.A.; Schan, M.K.; Rasmunsen, J.A. Plant Growth Regulators 1983 , 251.

24. Elakovich, S.D. In Terpenoid as Model for New Agrochemicals; Cutler, H.G., Ed., ACS, 1988).

25. Mann, J. Tetrahedron 1986, 4611.

26. Perrin, D.D.; Armarego, W.L.F. In Purification of Laboratory Chemicals; Pergamon Press; Oxford, 1988. 